Volume 5 Issue 2, September 2020:pp.215-229 Copyright @ LamLaj. Faculty of Law, Lambung Mangkurat University, Banjarmasin, South Kalimantan, Indonesia. ISSN: 2502-3136 | e-ISSN: 2502-3128. Open Access at: http://lamlaj.ulm.ac.id/web/

\title{
KONSEP HUKUM WHISTLEBLOWER DALAM HUKUM POSITIF INDONESIA
}

\author{
Yasmin Khairiyyah"1, Dwiyanti Agustina² \\ Fakultas Hukum Universitas Airlangga \\ Jalan Airlangga No. 4-6, Surabaya \\ kysminn01@gmail.com
}

Fakultas Hukum Universitas Balikpapan

Jalan Pupuk Raya, Gunung Bahagia, Balikpapan

dwiyantia70@gmail.com

Submitted : 14/06/2020 Reviewed:25/09/2020 Accepted:30/09/2020

\begin{abstract}
The terminology of Whistleblower was introduced in Indonesia in the Law of the Republic of Indonesia Number 31 of 1999 concerning Eradication of Corruption. In the law, a whistleblower known as Pelapor. However until now Indonesia hasn't yet comprehensively regulated about Pelapor so that it has implications for the narrow legal concept of Pelapor which limits criminal acts that can be reported. The research objective is to find out the concept of the Pelapor in Indonesia's law today and to hold legal reforms to the concept of Pelapor in Indonesia. The research method is juridical-normative by using a conceptual approach and a micro legal comparison approach at the legal concept level. The results of this study (1) The legal concept of the Pelapor in Indonesia's law currently emphasizes the Pelapor as a person who knows and provides reports relating to certain serious criminal acts or other organized criminal acts which are oriented only to law enforcement. (2) The legal concept of the Pelapor in Indonesia's future law will expand the criminal acts that can be reported by the Pelapor, namely by providing limits on the form of criminal acts and not only oriented towards law enforcement but also countermeasures by referring to the rules regarding Whistleblowers in South Africa namely the Witness Protection Act 112 of 1998 and the Protected Disclosures Act 26 of 2000.
\end{abstract}

Keywords: Comparative Law; Legal Concept; Pelapor; Whistleblower

Abstrak: Terminologi Whistleblower mulai diperkenalkan di Indonesia dalam Undang-Undang Republik Indonesia Nomor 31 Tahun 1999 tentang Pemberantasan Tindak Pidana Korupsi. Dalam undang-undang tersebut, whistleblower dikenal 
dengan istilah Pelapor. Meski begitu, hingga saat ini Indonesia belum mengatur secara komprehensif terkait Pelapor sehingga memberikan implikasi terhadap sempitnya konsep hukum Pelapor. Tujuan penelitian adalah untuk mengetahui konsep Pelapor dalam hukum positif di Indonesia saat ini dan untuk diadakannya legal reform terhadap konsep hukum Pelapor di Indonesia. Metode penelitian adalah yuridis-normatif dengan menggunakan pendekatan konseptual dan pendekatan perbandingan hukum secara mikro pada tingkatan legal concept. Hasil penelitian ini (1) Konsep hukum Pelapor dalam aturan hukum positif di Indonesia saat ini menekankan Pelapor sebagai seorang yang mengetahui dan memberikan laporan terkait tindak pidana tertentu yang bersifat serius maupun tindak pidana lainnya yang bersifat terorganisir yang mana hanya berorientasi pada penegakan hukum. (2) Konsep hukum Pelapor di Indonesia di masa yang akan datang akan memperluas tindak pidana yang dapat dilaporkan oleh Pelapor yaitu dengan tindak memberikan batasan terhadap bentuk tindak pidana dan tidak hanya berorientasi pada penegakan hukum namun juga penanggulangan dengan merujuk pada aturan mengenai Whistleblower yang ada di Afrika Selatan yaitu Witness Protection Act 112 of 1998 dan Protected Disclosures Act 26 of 2000.

Kata Kunci: Konsep Hukum; Pelapor; Perbandingan Hukum; Whistleblower.

\section{PENDAHULUAN}

Pembahasan mengenai Whistleblower merupakan pembahasan yang menarik terutama dari segi konsepsinya. Terminologi Whistleblower sendiri berasal dari Bahasa Inggris yang berarti "peniup peluit", hal ini dikarenakan whistleblower dianalogikan sebagai wasit dalam suatu pertandingan olahraga yang meniup peluit sebagai tanda telah terjadinya pelanggaran. Sedangkan dalam konteks hukum, whistleblower diartikan sebagai orang yang mengungkapkan fakta kepada publik terkait adanya suatu skandal, tindakantindakan yang sifatnya berbahaya, malpraktik atau korupsi serta tindak pidana lainnya. ${ }^{1} \mathrm{Di}$ Indonesia, terminologi Whistleblower mulai diperkenalkan dalam Undang-Undang Republik Indonesia Nomor 31 Tahun 1999 ten-

\footnotetext{
Lilik Mulyadi, Perlindungan Hukum Whistleblower dan Justice Collaborator dalam Upaya Penanggulangan Organized Crime, (Bandung: Alumni, 2015), 1
}

tang Pemberantasan Tindak Pidana Korupsi dengan sebutan Pelapor dan diartikan sebagai orang yang memberi informasi kepada penegak hukum mengenai terjadinya suatu tindak pidana korupsi.

Hingga saat ini, belum ada aturan di Indonesia yang secara komprehensif mengatur tentang Whistleblower, namun secara selintas telah diatur dalam beberapa peraturan, yaitu sebagai berikut:

1. Undang-Undang Nomor 31 Tahun 1999 tentang Pemberantasan Tindak Pidana Korupsi juncto Undang-Undang Nomor 20 Tahun 2001 tentang Perubahan Atas Undang-Undang Nomor 31 Tahun 1999 tentang Pemberantasan Tindak Pidana Korupsi

2. Undang-Undang Nomor 13 Tahun 2006 tentang Perlindungan Saksi dan Korban juncto Undang-Undang Nomor 31 Tahun 2014 tentang Perubahan Atas UndangUndang Nomor 13 Tahun 2006 tentang 
Perlindungan Saksi dan Korban

3. Undang-Undang Nomor 37 Tahun 2008 tentang Ombudsman Republik Indonesia

4. Undang-Undang Nomor 8 Tahun 2010 tentang Pencegahan dan Pemberantasan Tindak Pidana Pencucian Uang

5. Peraturan Pemerintah Republik Indonesia Nomor 71 Tahun 2000 tentang Tata Cara Pelaksanaan Peran Serta Masyarakat Dan Pemberian Penghargaan Dalam Pencegahan dan Pemberantasan Tindak Pidana Korupsi

6. Peraturan Pemerintah Republik Indonesia Nomor 57 Tahun 2003 tentang Tata Cara Perlindungan Khusus Bagi Pelapor dan Saksi Tindak Pidana Pencucian Uang

7. Peraturan Bersama Menteri Hukum Dan Hak Asasi Manusia Republik Indonesia, Jaksa Agung Republik Indonesia, Kepala Kepolisian Negara Republik Indonesia, Komisi Pemberantasan Korupsi Republik Indonesia, Ketua Lembaga Perlindungan Saksi dan Korban Republik Indonesia Nomor: $\quad$ M.HH-11.HM.03.02.Th.2011, Nomor: PER-045/A/JA/12/2011, Nomor : 1 Tahun 2011, Nomor: KEPB-02/0155/12/2011, dan Nomor: 4 Tahun 2011 Tentang Perlindungan Bagi Pelapor, Saksi Pelapor dan Saksi Pelaku Yang Bekerjasama

8. Peraturan Menteri Pendayagunaan Aparatur Negara Dan Reformasi Birokrasi Republik Indonesia Nomor 2 Tahun 2013 tentang Pedoman Umum Sistem Penanganan Pengaduan (Whistleblower System) Tindak Pidana Korupsi Di Lingkungan Kementerian Pendayagunaan Aparatur Negara Dan Reformasi Birokrasi

9. Surat Edaran Mahkamah Agung Nomor 4 Tahun 2011 tentang Perlakuan Bagi Pelapor Tindak Pidana (Whistle Blower) dan
Saksi Pelaku yang Bekerjasama (Justice Collaborator) di dalam Perkara Tindak Pidana Tertentu

Secara garis besar, dalam aturan-aturan tersebut memaknai Pelapor sebagai seorang yang mengetahui dan memberikan laporan atau informasi dalam konteks hukum tindak pidana tertentu yang bersifat serius seperti tindak pidana korupsi, terorisme, tindak pidana narkotika, tindak pidana pencucian uang, perdagangan orang, maupun tindak pidana lainnya yang bersifat terorganisir dan melaporkannya kepada penegak hukum atau pejabat yang berwenang.

Dari sekian banyak aturan yang telah disebutkan, hingga saat ini belum ada aturan yang secara komprehensif mengatur terkait Pelapor yang mana hal ini menimbulkan permasalahan yang memberikan implikasi besar terhadap konsep dari Pelapor itu sendiri yang dimaknai secara sempit. Sebenarnya, pemaknaan Pelapor yang secara sempit ini tidak terlepas dari awal mula penggunaan terminologi Pelapor yang diwujudkan dalam rangka pengungkapan tindak pidana terorganisir di Indonesia yaitu tindak pidana korupsi. Salah satu contoh Pelapor yang masih hangat dalam ingatan adalah Sudirman Said yang melaporkan Setya Novanto ke Mahkamah Kehormatan Dewan dalam kasus "Papa Minta Saham" pada tanggal 16 November 2015 silam. Saat itu Sudirman Said masih menjabat sebagai Menteri Energi dan Sumber Daya Mineral Republik Indonesia, yang melaporkan Setya Novanto ke Mahkamah Kehormatan Dewan atas dugaan Setya Novanto telah meminta sejumlah saham PT. Freeport Indonesia dengan mengatasnamakan Presiden dan Wakil Presiden Republik Indonesia. ${ }^{2}$ Tidak kalah popul-

\footnotetext{
Andre Jason, “Kasus 'Papa Minta Saham' Dan Kondisi Whistleblowing Di Indonesia," Medium,
} 
er dengan kasus "Papa Minta Saham", kasus lain terkait Pelapor dalam tindak pidana korupsi adalah Stanley Ering yang mengadukan Rektor Universitas Negeri Manado (UNIMA) ke kejaksaan Tinggi Sulawesi Utara dan KPK pada tahun 2011, serta Daud Ndakularak yang melaporkan tindak pidana korupsi terhadap pengelolaan dana kas APBD Kabupaten Sumba Timur TA 2005-2006. ${ }^{3}$ Dari ketiga contoh kasus tersebut, dapat dilihat "menyempitnya" makna dari seorang Pelapor yang lebih dianggap sebagai ranah dalam hukum pidana khusus pada tindak pidana korupsi.

Dengan masih terbatasnya aturan-aturan tersebut, perlu diadakan sebuah legal reform atau reformasi hukum untuk dapat membawa eksistensi kedudukan Pelapor pada wilayah hukum yang lebih luas, tidak hanya berfokus pada ranah hukum pidana khusus saja, namun diharapkan dapat dibawa ke ranah hukum pidana umum secara lebih luas. Berdasarkan hal-hal tersebut, rumusan masalah dalam penelitian ini terbatas pada:

1. Bagaimana konsep hukum Whistleblower atau yang dalam hukum positif di Indonesia?

2. Bagaimana konsep Whistleblower yang diharapkan dalam hukum positif di Indonesia di masa yang akan datang?

\section{METODE}

Penelitian ini adalah penelitian yuridis normatif yang bersifat deskriptif analitis, den-

last modified 2017, accessed May 14, 2020, https:// medium.com/@andrejason14/kasus-papa-mintasaham-dan-kondisi-whistleblowing-di-indonesia1c2bf3ae20bc.

3 "Dua Pelapor (Whistleblower) Korupsi Yang Dilindungi LPSK Justru Terancam Masuk Penjara," (ICJR) Institute For Criminal Justice Reform, last modified 2017, accessed May 2, 2020, https://icjr. or.id/dua-pelapor-whistleblower-korupsi-yangdilindungi-lpsk-justru-terancam-masuk-penjara/. gan menggunakan pendekatan konseptual, pendekatan peraturan perundang-undangan, dan pendekatan perbandingan hukum mikro pada tingkatan legal concept dengan berfokus pada perluasan konsep dari Pelapor. Dalam pendekatan perbandingan hukum, akan digunakan salah satu metode yang ada dalam perbandingan hukum yaitu Functional Method untuk melakukan perbandingan hukum berdasarkan adanya kesamaan fungsi yang sama atau dari dua peraturan yang berbeda untuk dapat digunakan sebagai solusi menyelesaikan permasalahan hukum yang sama, dalam hal ini akan melakukan perbandingan dengan aturan terkait Pelapor yang ada di Afrika Selatan.

Penelitian ini menggunakan sumber berupa bahan hukum, antara lain peraturan perundang-undangan, di antaranya UndangUndang Nomor 31 Tahun 1999 tentang Pemberantasan Tindak Pidana Korupsi juncto Undang-Undang Nomor 20 Tahun 2001 tentang Perubahan Atas Undang-Undang Nomor 31 Tahun 1999 tentang Pemberantasan Tindak Pidana Korupsi, Undang-Undang Nomor 13 Tahun 2006 tentang Perlindungan Saksi dan Korban jo. Undang-Undang Nomor 31 Tahun 2014 tentang Perubahan Atas Undang-Undang Nomor 13 Tahun 2006 tentang Perlindungan Saksi dan Korban, Undang-Undang Nomor 37 Tahun 2008 tentang Ombudsman Republik Indonesia, Undang-Undang Nomor 8 Tahun 2010 tentang Pencegahan dan Pemberantasan Tindak Pidana Pencucian Uang, Peraturan Pemerintah Republik Indonesia Nomor 71 Tahun 2000 tentang Tata Cara Pelaksanaan Peran Serta Masyarakat Dan Pemberian Penghargaan Dalam Pencegahan Dan Pemberantasan Tindak Pidana Korupsi, Peraturan Pemerintah Republik Indonesia Nomor 57 Tahun 2003 tentang Tata Cara 
Perlindungan Khusus Bagi Pelapor Dan Saksi Tindak Pidana Pencucian Uang, Peraturan Bersama Menteri Hukum Dan Hak Asasi Manusia Republik Indonesia, Jaksa Agung Republik Indonesia, Kepala Kepolisian Negara Republik Indonesia, Komisi Pemberantasan Korupsi Republik Indonesia, Ketua Lembaga Perlindungan Saksi dan Korban Republik Indonesia Nomor: M.HH-11.HM.03.02. Th.2011, Nomor: PER-045/A/JA/12/2011, Nomor : 1 Tahun 2011, Nomor : KEPB02/01-55/12/2011, dan Nomor: 4 Tahun 2011 Tentang Perlindungan Bagi Pelapor, Saksi Pelapor dan Saksi Pelaku Yang Bekerjasama, Peraturan Menteri Pendayagunaan Aparatur Negara Dan Reformasi Birokrasi Republik Indonesia Nomor 2 Tahun 2013 tentang Pedoman Umum Sistem Penanganan Pengaduan (Whistleblower System) Tindak Pidana Korupsi Di Lingkungan Kementerian Pendayagunaan Aparatur Negara Dan Reformasi Birokrasi, dan Surat Edaran Mahkamah Agung Nomor 4 Tahun 2011 tentang Perlakuan Bagi Pelapor Tindak Pidana (Whistle Blower) dan Saksi Pelaku yang Bekerjasama (Justice Collaborator) di dalam Perkara Tindak Pidana Tertentu, serta aturan terkait Pelapor yang ada di Afrika Selatan yaitu Witness Protection Act 112 of 1998 dan Protected Disclosures Act 26 of 2000. Selain itu juga menggunakan literatur dan kamus hukum, serta bahan-bahan non-hukum yang memiliki keterkaitan dengan isu yang dibahas. Dalam pengumpulan bahan hukum, dilakukan studi kepustakaan dengan menganalisis konsep Pelapor dalam peraturan perundang-undangan yang ada di Indonesia dan di Afrika Selatan serta literatur yang berkaitan dengan Whistleblower, kemudian diolah dan dianalisis secara sistematis untuk memperoleh kesimpulan yang sesuai dengan tujuan penelitian.

\section{ANALISIS DAN PEMBAHASAN Konsep Hukum Whistleblower di Indone- sia}

Terminologi Pelapor sebenarnya secara abstrak telah ada dalam Undang-Undang Nomor 8 Tahun 1981 tentang Kitab UndangUndang Hukum Acara Pidana namun tidak diposisikan sebagai subjek hukum, melainkan sebagai obyek hukum yang disebut dengan Laporan. Laporan dalam Pasal 1 angka 24 Undang-Undang Nomor 8 Tahun 1981 tentang Kitab Undang-Undang Hukum Acara Pidana diartikan sebagai suatu pemberitahuan yang disampaikan oleh seorang karena atau kewajiban berdasarkan undang-undang kepada pejabat yang berwenang tentang telah atau sedang atau diduga akan terjadinya peristiwa pidana. Hal ini berbeda dengan konsep Whistleblower yang sesungguhnya yaitu seseorang yang mengungkapkan fakta kepada khalayak umum/publik terkait suatu skandal, tindakantindakan yang berbahaya, malpraktik atau korupsi serta tindak pidana lainnya. ${ }^{4}$

Seiring berjalannya waktu, terminologi Pelapor mulai disebutkan lebih jelas dalam Undang-Undang Nomor 31 Tahun 1999 tentang Pemberantasan Tindak Pidana Korupsi. Kemudian diikuti dengan beberapa peraturan hukum positif di Indonesia yang memberikan terminologi dan penjelasan konsep Pelapor secara selintas. Berikut diuraikan konsep dari seorang Pelapor dalam aturan hukum di Indonesia, diantaranya:

1. Undang-Undang Nomor 31 Tahun 1999 tentang Pemberantasan Tindak Pidana Korupsi

Dalam undang-undang ini mengartikan

\footnotetext{
${ }^{4}$ Mulyadi, Perlindungan Hukum Whistleblower dan Justice Collaborator dalam Upaya Penanggulangan Organized Crime, 1-2.
} 
Pelapor sebagai orang yang memberi informasi kepada penegak hukum mengenai terjadinya suatu tindak pidana korupsi dan bukan pelapor sebagaimana dimaksud dalam Pasal 1 angka 24 Undang-Undang Nomor 8 Tahun 1981 tentang Hukum Acara Pidana. Yang dimaksud dalam Pasal 1 angka 24 tersebut adalah perihal laporan yaitu pemberitahuan yang disampaikan oleh seorang karena atau kewajiban berdasarkan undang-undang kepada pejabat yang berwenang tentang telah atau sedang atau diduga akan terjadinya peristiwa pidana.

2. Undang-Undang Nomor 13 Tahun 2006 tentang Perlindungan Saksi Dan Korban Dalam undang-undang ini, yang dimaksud dengan Pelapor adalah orang yang memberikan informasi kepada penegak hukum mengenai terjadinya suatu tindak pidana.

3. Undang-Undang Nomor 37 Tahun 2008 tentang Ombudsman Republik Indonesia Dalam undang-undang ini, Pelapor diartikan sebagai warga negara Indonesia atau penduduk yang memberikan Laporan kepada Ombudsman.

4. Undang-Undang Nomor 8 Tahun 2010 Tentang Pencegahan dan Pemberantasan Tindak Pidana Pencucian Uang

Dalam undang-undang ini, Pihak Pelapor adalah Setiap Orang yang menurut Undang-Undang ini wajib menyampaikan laporan kepada PPATK.

5. Undang-Undang Nomor 31 Tahun 2014 tentang Perubahan Atas Undang-Undang Nomor 13 Tahun 2006 tentang Perlindungan Saksi dan Korban

Dalam undang-undang ini, yang dimaksud dengan Pelapor adalah orang yang memberikan laporan, informasi, atau ket- erangan kepada penegak hukum mengenai tindak pidana yang akan, sedang, atau telah terjadi, yang mana tindak pidana yang dimaksud dalam pasal ini adalah tindak pidana dalam kasus tertentu.

6. Peraturan Pemerintah Republik Indonesia Nomor 71 Tahun 2000 tentang Tata Cara Pelaksanaan Peran Serta Masyarakat Dan Pemberian Penghargaan Dalam Pencegahan Dan Pemberantasan Tindak Pidana Korupsi

Dalam peraturan ini, mengartikan Pelapor sebagai orang yang memberi suatu informasi kepada penegak hukum atau Komisi mengenai terjadinya suatu tindak pidana korupsi dan bukan pelapor sebagaimana dimaksud dalam Pasal 1 angka 24 Undang-Undang Nomor 8 Tahun 1981 tentang Hukum Acara Pidana.

7. Peraturan Pemerintah Republik Indonesia Nomor 57 Tahun 2003 tentang Tata Cara Perlindungan Khusus Bagi Pelapor Dan Saksi Tindak Pidana Pencucian Uang Yang dimaksud Pelapor dalam peraturan ini adalah setiap orang yang karena kewajibannya berdasarkan peraturan perundang-undangan menyampaikan laporan kepada PPATK tentang Transaksi Keuangan Mencurigakan atau Transaksi Keuangan yang Dilakukan Secara Tunai sebagaimana dimaksud dalam Undangundang atau secara sukarela melaporkan kepada penyidik tentang adanya dugaan terjadinya tindak pidana pencucian uang sebagaimana dimaksud dalam Undangundang.

8. Peraturan Bersama Menteri Hukum Dan Hak Asasi Manusia Republik Indonesia, Jaksa Agung Republik Indonesia, Kepala Kepolisian Negara Republik Indonesia, Komisi Pemberantasan Korupsi Republik 
Indonesia, Ketua Lembaga Perlindungan Saksi dan Korban Republik Indonesia Nomor: M.HH-11.HM.03.02.Th.2011, Nomor : PER-045/A/JA/12/2011, Nomor: 1 Tahun 2011, Nomor: KEPB-02/0155/12/2011, dan Nomor: 4 Tahun 2011 Tentang Perlindungan Bagi Pelapor, Saksi Pelapor dan Saksi Pelaku yang Bekerjasama

Dalam peraturan ini, Pelapor adalah orang yang mengetahui dan memberikan laporan serta informasi tentang terjadinya atau akan terjadinya suatu tindak pidana tertentu kepada penegak hukum dan bukan merupakan bagian dari pelaku kejahatan yang dilaporkannya.

9. Peraturan Menteri Pendayagunaan Aparatur Negara dan Reformasi Birokrasi Republik Indonesia Nomor 2 Tahun 2013 tentang Pedoman Umum Sistem Penanganan Pengaduan (Whistleblower System) Tindak Pidana Korupsi Di Lingkungan Kementerian Pendayagunaan Aparatur Negara Dan Reformasi Birokrasi

Dalam peraturan ini, terminologi yang digunakan bukan Pelapor, melainkan Whistle Blower, yaitu seseorang yang melaporkan perbuatan yang berindikasi Tindak Pidana Korupsi (TPK) yang terjadi di dalam organisasi tempatnya bekerja atau pihak terkait lainnya yang ia memiliki akses informasi yang memadai atas terjadinya indikasi tindak pidana korupsi tersebut.

10. Surat Edaran Mahkamah Agung Nomor 4 Tahun 2011 tentang Perlakuan Bagi Pelapor Tindak Pidana (Whistle Blower) dan Saksi Pelaku yang Bekerjasama (Justice Collaborator) di dalam Perkara Tindak Pidana Tertentu

Dalam Surat Edaran ini, yang dimaksud dengan Pelapor Tindak Pidana adalah pihak yang mengetahui dan melaporkan tindak pidana tertentu dan bukan merupakan bagian dari pelaku kejahatan yang dilaporkannya, yang mana tindak pidana tertentu yang bersifat serius adalah tindak pidana seperti tindak pidana korupsi, terorisme, tindak pidana narkotika, tindak pidana pencucian uang, perdagangan orang, maupun tindak pidana lainnya yang bersifat terorganisir.

Selain dalam aturan-aturan tersebut, para Sarjana juga memberikan pendapat konsep Whistleblower diantaranya:

1. Mulyana Wirakusumah Menurut Mulyana, whistleblower bukan hanya sekedar "tukang mengadu" tetapi juga sebagai saksi dari suatu kejahatan. Lebih lanjut, Beliau juga berpendapat bahwa whistleblower merupakan orang yang bekerja dalam suatu Kementerian/ Satuan Kerja Perangkat Daerah atau lembaga lain yang memiliki akses informasi dan mengadukan perbuatan yang terindikasi adanya penyimpangan. ${ }^{5}$

2. Mardjono Reksodiputro Menurut Mardjono, whistleblower adalah seorang pembocor rahasia atau pengadu, artinya seseorang tersebut membocorkan informasi yang sebenarnya bersifat rahasia dikalangan informasi itu berada. ${ }^{6} \mathrm{Be}-$ liau juga mengkategorikan whistleblower sebagai justice collaborator karena termasuk orang yang bekerjasama dengan penegak hukum. ${ }^{7}$

3. Imam Thurmudhin

\footnotetext{
${ }_{5}^{5}$ Mulyadi, Perlindungan Hukum Whistleblower dan Justice Collaborator dalam Upaya Penanggulangan Organized Crime, 41.

6 Ibid, 42.

7 Ibid, 44.
} 
Menurut Beliau, seseorang dapat dikatakan sebagai whistleblower apabila orang tersebut melihat sendiri, mendengar sendiri, atau mengalami sendiri suatu tindak pidana atau pelanggaran dan dengan itikad baik mengungkapkan kepada publik atau melaporkan kepada pejabat yang berwenang. ${ }^{8}$

4. Firman Wijaya

Beliau mendefinisikan whistleblower sebagai suatu bentuk peran serta masyarakat atas kesadaran diri untuk membantu penegak hukum dalam mengungkap dan melaporkan suatu tindak pidana yang tidak diketahui yang sebelumnya tidak diketahui oleh banyak orang bahkan penegak hukum itu sendiri. ${ }^{9}$

5. Lilik Mulyadi

Berbeda dengan para sarjana sebagaimana diuraikan, Lilik Mulyadi memilih untuk mengartikan whistleblower sesuai dengan perannya, yaitu:

a. Whistleblower berperan sebagai "pelapor", artinya yang bersangkutan tidak secara langsung mendengar, melihat ataupun mengetahui pelaksanaan suatu tindak pidana, tegasnya hanya sebatas mengetahui informasi yang selanjutnya bermanfaat terhadap suatu pengungkapan fakta tindak pidana oleh penegak hukum. ${ }^{10}$

b. Whistleblower berperan sebagai "saksi pelapor", artinya yang bersangkutan adalah seorang pengungkap fakta yang melaporkan dan secara langsung

8 Ibid, 43.

9 Agus Kasiyanto, Tindak Pidana Korupsi Pada Proses Pengadaan Barang \& Jasa, (Jakarta: Kencana, 2018), 47.

${ }^{10}$ Mulyadi, Perlindungan Hukum Whistleblower dan Justice Collaborator dalam Upaya Penanggulangan Organized Crime, 57. mengetahui, melihat dan mengalami sendiri telah, sedang, atau akan terjadinya suatu tindak pidana yang secara aktif melaporkannya pada aparat penegak hukum yang berwenang. ${ }^{11}$

Dari uraian tersebut, dapat disimpulkan yang dimaksud dengan Pelapor adalah seseorang yang mengetahui dan memberikan laporan atau informasi dalam konteks hukum tindak pidana tertentu yang bersifat serius seperti tindak pidana korupsi, terorisme, tindak pidana narkotika, tindak pidana pencucian uang, perdagangan orang, maupun tindak pidana lainnya yang bersifat terorganisir dan melaporkannya kepada penegak hukum atau pejabat yang berwenang. Pelapor dapat menjadi seorang saksi apabila terhadap informasi tersebut diketahui, dilihat, dan dialami sendiri secara langsung.

Dalam Pasal 1 angka 4 Undang-Undang Nomor 31 Tahun 2014 tentang Perubahan Atas Undang-Undang Nomor 13 Tahun 2006 tentang Perlindungan Saksi dan Korban yang pada pokoknya menyatakan bahwa pelapor adalah orang yang memberikan informasi kepada penegak hukum mengenai terjadinya suatu tindak pidana. Selanjutnya dalam Pasal 31 ayat (1) Undang-Undang Nomor 31 Tahun 1999 tentang Pemberantasan Tindak Pidana Korupsi, Pasal 3 ayat (1) Peraturan Pemerintah Republik Indonesia Nomor 71 Tahun 2000 tentang Tata Cara Pelaksanaan Peran Serta Masyarakat dan Pemberian Penghargaan Dalam Pencegahan Dan Pemberantasan Tindak Pidana Korupsi, Pasal 1 angka 3 Peraturan Menteri Pendayagunaan Aparatur Negara dan Reformasi Birokrasi Republik Indonesia Nomor 2 Tahun 2013 tentang Pedoman Umum Sistem Penanganan Pengaduan (Whistleblower System) Tindak Pidana Ko-

11 Ibid, 64. 
rupsi Di Lingkungan Kementerian Pendayagunaan Aparatur Negara Dan Reformasi Birokrasi, pada pokok dapat disimpulkan konsep seorang Pelapor dibatasi hanya sebagai orang yang melaporkan suatu tindak pidana korupsi kepada penegak hukum. Kemudian dalam Pasal 1 angka 11 Undang-Undang Nomor 8 Tahun 2010 Tentang Pencegahan Dan Pemberantasan Tindak Pidana Pencucian Uang, Pasal 1 angka 2 Peraturan Pemerintah Republik Indonesia Nomor 57 Tahun 2003 tentang Tata Cara Perlindungan Khusus Bagi Pelapor Dan Saksi Tindak Pidana Pencucian Uang, pada pokoknya membatasi konsep Pelapor sebagai seorang yang melaporkan suatu tindak pidana pencucian uang kepada penegak hukum.

Konsep pelaporan suatu tindak pidana dari seorang Pelapor mulai diperluas dalam Peraturan Bersama Menteri Hukum dan Hak Asasi Manusia Republik Indonesia, Jaksa Agung Republik Indonesia, Kepala Kepolisian Negara Republik Indonesia, Komisi Pemberantasan Korupsi Republik Indonesia, Ketua Lembaga Perlindungan Saksi dan Korban Republik Indonesia Nomor: M.HH-11. HM.03.02.Th.2011, Nomor: PER-045/A/ JA/12/2011, Nomor: 1 Tahun 2011, Nomor : KEPB-02/01-55/12/2011, dan Nomor: 4 Tahun 2011 Tentang Perlindungan Bagi Pelapor, Saksi Pelapor dan Saksi Pelaku Yang Bekerjasama dan Surat Edaran Mahkamah Agung Nomor 4 Tahun 2011 tentang Perlakuan Bagi Pelapor Tindak Pidana (Whistle Blower) dan Saksi Pelaku yang Bekerjasama (Justice Collaborator) di dalam Perkara Tindak Pidana Tertentu yakni pada suatu tindak pidana tertentu yang bersifat serius seperti tindak pidana korupsi, terorisme, tindak pidana narkotika, tindak pidana pencucian uang, perdagangan orang, maupun tindak pidana lainnya yang bersifat terorganisir.

Konsep-konsep whistleblower yang berbeda-beda seperti yang telah diuraikan merupakan akibat dari tidak adanya suatu aturan khusus yang secara komprehensif mengatur tentang whistleblower. Dengan masih adanya perbedaan konsep whistleblower memberikan implikasi terhadap hingga tahap mana kedudukan seseorang dapat disebut sebagai whistleblower. Pada tahap penyidikan, kedudukan whistleblower menjadi sangat penting dikarenakan dengan adanya whistleblower akan membantu tugas penyidik untuk menuntaskan suatu perkara sampai kepada intellectualdader dan pimpinan organisasi kejahatan. ${ }^{12}$ Lebih lanjut, apabila konsep whistleblower telah sampai pada tingkatan persidangan, secara tidak langsung kedudukan whistleblower akan bergeser menjadi seorang Saksi pula.

Dengan tidak adanya konsep whistleblower yang secara komprehensif diatur sehingga masih terbatasinya tindak pidana yang dapat dilaporkan oleh seorang whistleblower, menimbulkan pula permasalahan dalam bentuk perlindungan hukum yang diberikan. Hal dini dikarenakan bentuk perlindungan hukum yang diberikan kepada seorang Pelapor tentu tidak akan sama dengan seorang Saksi. ${ }^{13}$

\section{Konsep Hukum Whistleblower di Indone- sia di Masa Yang Akan Datang}

Bersesuaian dengan tujuan dari penelitian ini yaitu untuk terciptanya legal reform salah

\footnotetext{
${ }^{12}$ Rusli Muhammad, "Pengaturan dan Urgensi Whistle Blower dan Justice Collaborator dalam Sistem Peradilan Pidana," Jurnal Hukum IUS QUIA IUSTUM 22, No. 2 (2015): 214, https://journal.uii.ac.id/index. php/IUSTUM/article/view/5117.

${ }^{13}$ Puteri Hikmawati, "Upaya Perlindungan Whistleblower dan Justice Collaborator dalam Tindak Pidana Korupsi," Negara Hukum 4, No. 1 (2013): 102, https://jurnal.dpr.go.id/index.php/hukum/article/ view/197.
} 
satunya adalah dengan melalui perbandingan hukum terhadap aturan terkait whistleblower yang ada di negara Afrika Selatan. Dipilihnya Afrika Selatan sebagai bahan perbandingan hukum, dikarenakan aturan terkait Pelapor di Afrika Selatan yaitu Protected Disclosures Act 26 of 2000 telah memiliki aturan yang secara komprehensif mengatur perihal Pelapor dan telah menghilangkan batasan-batasan terhadap bentuk tindak pidana yang dapat dilaporkan oleh seorang Pelapor.

Salah satu contoh kasus yang menjadi cikal bakal tidak perlunya dibatasinya tindak pidana yang dapat dilaporkan oleh seorang whistleblower adalah kasus yang terjadi di Jakarta Timur pada beberapa waktu lalu. SAP yang berusia 19 tahun tidak berani untuk melaporkan perbuatan CS, suaminya, yang kerap kali melakukan tindak pidana penganiayaan terhadap puteranya yang berusia 2 tahun hingga akhirnya meninggal dunia. ${ }^{14}$ Kasus tersebut merupakan salah satu dari banyak kasus lain yang terjadi di Indonesia, dimana orang yang mengetahui terjadinya suatu tindak pidana cenderung takut dan tidak berani mengungkapkan tindak pidana tersebut dengan pertimbangan bahwa tindak pidana tersebut bukan tindak pidana yang merugikan khalayak umum. Hal ini dikarenakan tidak adanya payung hukum atau aturan yang sudah secara komprehensif sehingga terkesan acuh. Oleh karena itu, dibutuhkan adanya perluasan dari konsep Whistleblower guna memberikan payung hukum dan kepastian hukum utamanya memberikan perlindungan keselamatan

\footnotetext{
14 "Kerap Lihat Anak Yang Masih Balita Dianiaya, Sang Ibu Tak Berani Laporkan Suami Kedua ke Polisi," WartaKotaLive, last modified 2020, Accessed September 4, 2020. https://wartakota.tribunnews. com/2020/07/17/kerap-lihat-anak-yang-masih-balitadianiaya-sang-ibu-tak-berani-laporkan-suami-keduake-polisi.
}

bagi pelapor.

Konsep hukum Whistleblower di Afrika Selatan lebih dikenal dengan istilah Pengungkap yang menjadi bahan rujukan. Seperti di Indonesia, awalnya perihal Pengungkap sendiri tidak diatur secara komprehensif dalam suatu aturan khusus karena pada masa itu masih berfokus pada perlindungan terhadap Saksi. Undang-undang yang berlaku di Afrika Selatan pada masa itu adalah Witness Protection Act 112 of 1998, yang mana undang-undang tersebut dipengaruhi sebelum Strategi Nasional Pencegahan Kejahatan 1996 diadopsi. Aturan terkait saksi di Afrika Selatan pada saat itu masih mengacu pada Pasal 185 A dari Undang-Undang Hukum Pidana Afrika Selatan tahun 1977.

Ketentuan hukum yang ada pada UndangUndang Hukum Pidana Afrika Selatan tahun 1977 masih bersifat represif dan digunakan pada saat rezim apartheid sebagai upaya untuk memaksa saksi untuk memberikan pembuktiannya. Strategi tahun 1996 mengakui perlindungan saksi sebagai alat kunci dalam mengamankan bukti dari saksi-saksi rentan dan terintimidasi dalam proses peradilan dan mengakui bahwa perlindungan saksi, pada saat itu, adalah titik lemah dalam sistem penegakan hukum. ${ }^{15}$

Setelah diundangkannya Witness Protection Act 112 of 1998, Afrika Selatan mulai bergerak cepat untuk mengatur secara khusus perlindungan terhadap seorang Pengungkap sehingga kembali diundangkan dalam Protected Disclosures Act 26 of 2000. Berikut dapat diuraikan bagaimana Afrika Selatan mengkonsep seorang Pengungkap dalam

\footnotetext{
${ }^{15}$ UNODC, Praktek Terbaik Perlindungan Saksi Dalam Proses Pidana Yang Melibatkan Kejahatan Terorganisir ( Jakarta: Lembaga Perlindungan Saksi dan Korban (LPSK), 2010), 13
} 
aturan hukumnya, yaitu:

\section{Witness Protection Act 112 of 1998}

Dalam Witness Protection Act 112 of 1998, yang berkaitan dengan Pengungkap pada pokoknya mendefinisikan jenis-jenis kejahatan yang dapat dijadikan dasar permohonan perlindungan oleh saksi, prosedur yang perlu ditaati dan orang-orang yang dapat mengajukan permohonan. Daftar tindak pidana tidak bersifat eksklusif karena direktur berwenang untuk menyetujui perlindungan bagi saksi dalam proses persidangan lainnya jika dianggap bahwa keamanan saksi tersebut memerlukan perlindungan. ${ }^{16}$

Secara garis besar, dalam undang-undang tersebut mengatur tentang dimensidimensi sebagai berikut: ${ }^{17}$

a. Membentuk Kantor Perlindungan Saksi nasional dibawah wewenang Menteri Hukum dan Perkembangan Konstitusional. Kantor tersebut dikepalai oleh direktur nasional dan memiliki kantor perwakilan pada Sembilan provinsi di Afrika Selatan. Meskipun belum ada amandemen peraturan, pada tahun 2001 kantor tersebut dirubah susunan menjadi bagian dari Lembaga Penuntutan Nasional dan semenjak itu dikenal sebagai Unit Perlindungan Saksi;

b. Mengatur fungsi dan tugas Direktur, termasuk wewenang untuk menentukan penerimaan kedalam program. Keputusan direktur didasarkan rekomendasi dari kepala kantor cabang dan petugas yang relevan dari lembaga penegak hukum serta Lembaga Penuntutan Nasional. Keputusan di-

\footnotetext{
${ }^{16}$ Ibid, 14.

${ }^{17}$ Ibid, 13-14.
}

rektur untuk menolak suatu permohonan atau melepaskan seorang dari perlindungan dapat ditinjau ulang oleh Menteri Hukum dan Perkembangan Konstitusional;

c. Mendefinisikan jenis-jenis kejahatan yang dapat dijadikan dasar permohonan perlindungan oleh saksi, prosedur yang perlu ditaati dan orang-orang yang dapat mengajukan permohonan. Daftar tindak pidana tidak bersifat eksklusif oleh karena Direktur berwenang untuk menyetujui perlindungan bagi saksi dalam proses persidangan lainnya jika dianggap bahwa keamanan saksi tersebut memerlukan perlindungan;

d. Menentukan bahwa proses persidangan perdata yang tertunda oleh karena saksi berada dalam perlindungan dapat ditangguhkan oleh hakim, dengan permohonan ex parte, untuk mencegah pengungkapan identitas atau lokasi saksi atau untuk mencapai tujuan undang-undang. Kantor Perlindungan Saksi menjadi alamat yang ditujukan dalam proses persidangan yang melibatkan saksi tersebut;

e. Mendefinisikan tindak pidana dan hukuman keras terhadap pengungkapan atau publikasi informasi mengenai orang yang berada dalam program atau petugas Kantor Perlindungan saksi agar memastikan keamanan saksi yang dilindungi serta petugas program. Keputusan pengungkapan informasi berada pada Direktur setelah mempertimbangkan perwakilan dan tanpa prasangka terhadap peraturan lain yang berlaku;

f. Memberikan wewenang kepada Men- 
teri Hukum dan Perkembangan Konstitusional untuk menandatangani perjanjian dengan Negara lain atau organisasi internasional yang mengatur kondisi dan kriteria relokasi saksi asing ke Afrika Selatan dan penerimaannya ke dalam program perlindungan saksi Afrika selatan. Relokasi tersebut membutuhkan persetujuan menteri.

2. Protected Disclosures Act 26 of 2000

Dalam Protected Disclosures Act 26 of 2000, dijelaskan bahwa, "Disclosure means any disclosure of info, mation regarding any conduct of an employer, or an employee of that employer, made by any employee who has reason to believe that the information concerned shows or tends to show one or more of the following:

a) That a criminal offence has been committed, is being committed or is likely to be committed;

b) that a person has failed, is failing or is likely to fail to comply with any legal obligation to which that person is subject;

c) that a miscarriage of justice has occurred, is occurring or is likely to occur;

d) that the health or safety of an individual has been, is being or is likely to be endangered;

e) that the environment has been, is being or is likely to be damaged;

f) unfair discrimination as contemplated in the Promotion of Equality and Prevention of Unfair Discrimination Act, 2000 (Act No, 4 of 2000); or

g) that any matter referred to in paragraphs (a) to (f) has been, is being or is likely to be deliberately concealed.
Dalam Protected Disclosures Act 26 of 2000, seorang Pengungkap dikonsepkan sebagai seorang yang melakukan segala pengungkapan informasi mengenai perilaku atasan atau karyawan, yang dibuat oleh karyawan lain, yang mana karyawan harus memiliki alasan untuk meyakini bahwa informasi tersebut memang benar dan sesuai fakta.

Berkaitan dengan konsep Pengungkap yang ada di Afrika Selatan, definisi suatu kejahatan yang dapat dilaporkan oleh seseorang dalam Witness Protection Act 112 of 1998 tidak bersifat eksklusif, artinya tidak ada suatu batasan bagi seorang Pengungkap terhadap "kejahatan" yang ia ketahui untuk dapat dilaporkan. Hal ini dikarenakan kedua undangundang tersebut telah menyetujui melindungi siapa saja yang kedudukannya dianggap sebagai seorang Pengungkap untuk memastikan keamanan dan keselamatannya, tanpa memandang tindak pidana apa yang dilaporkan. Lebih lanjut, dalam Protected Disclosures Act 26 of 2000 juga benar-benar berfokus pada keamanan dan keselamatan whistleblower. Hal tersebut dibuktikan dengan didahulukannya perlindungan bagi whistleblower dibanding dengan laporan/informasi yang diungkapkan oleh whistleblower. ${ }^{18}$

Dapat dilihat pada bunyi Pasal 3 Protected Disclosures Act 26 of 2000 yang dirumuskan sedemikian rupa untuk seorang Pengungkap yang jika ditelaah posisi Pengungkap dibatasi hanya sampai pada tahap penyelidikan dan penyidikan. Tidak ada pembahasan terkait persidangan yang dapat disimpulkan bahwa konsep Whistleblower pada Protected

\footnotetext{
${ }^{18}$ David Lewis and Tina Uys, "Protecting Whistleblowers at Work a Comparison of the Impact of British and South African Legislation," Managerial Law 49, No. 3 (2007): 87, https://www.emerald.com/insight/ content/doi/10.1108/03090550710816492/full/html.
} 
Disclosures Act 26 of 2000 adalah seseorang yang mengungkap suatu tindak pidana atau tidak terpenuhinya suatu kewajiban hukum atau suatu ketidakadilan atau kesehatan dan keselamatan seseorang sedang terancam. Dihilangkannya batasan terhadap tindak pidana yang dapat dilaporkan seorang Pelapor memberikan implikasi yang besar terhadap bentuk kepastian hukum seseorang untuk mendapat perlindungan hukum tanpa memandang tindak pidana yang dapat dilaporkan. Hal ini dikarenakan, berkaitan dengan latar belakang budaya "diam" di Afrika Selatan, Pemerintah ikut andil untuk mengubah image seorang Whistleblower yang tidak diperlakukan seperti seorang pengkhianat, namun diperlakukan seperti seorang pahlawan yang berani mengungkapkan kebenaran. ${ }^{19}$

Setelah memahami konsep hukum Pelapor di Indonesia dan konsep hukum Pengungkap di Afrika Selatan, maka sesuai dengan tujuan yang ingin dicapai dari hasil penelitian ini yaitu legal reform atau reformasi hukum yang mengacu dari permasalahan sebagaimana yang terurai yakni memperluas konsep hukum Pelapor di Indonesia di masa yang akan datang dengan merujuk pada Witness Protection Act 112 of 1998 dan Protected Disclosure Act 26 of 2000 yang disesuaikan dengan terminologi yang telah ada di Indonesia dengan rumusan sebagai berikut :

Pelapor adalah orang yang mengetahui dan mengungkap dengan bentuk memberikan laporan atau informasi terhadap telah terjadi, sedang terjadi atau kemungkinan besar akan terjadi suatu tindak

${ }_{19}$ S. Lubisi and H. Bezuidenhout, "Blowing the whistle for personal gain in the Republic of South Africa: An option for consideration in the fight against fraud ?", Southern African Journal of Accountability and Auditing Research 18 (2016): 56, http://hdl.handle. net/2263/58603. pidana atau suatu kegagalan yang mengakibatkan tidak terpenuhinya kewajiban hukum atau suatu ketidakadilan atau kesehatan dan keselamatan seseorang sedang terancam serta melaporkannya kepada penegak hukum atau pejabat yang berwenang.

Dari rumusan tersebut, maka beberapa hal yang ditegaskan dalam konsep hukum ini adalah :

1. Dalam konsep hukum Pelapor yang ada saat ini, apabila laporan yang diberikan oleh Pelapor memiliki "nilai" informasi yang diungkap hanya berfokus pada suatu penegakan hukum saja, namun dalam konsep hukum Pelapor yang baru ini, ditegaskan pula untuk penanggulangan suatu kondisi yang buruk akibat adanya suatu pelanggaran atau tindakan-tindakan yang merugikan orang lain.

2. Penghapusan batasan Pelapor dalam hal memberikan laporan agar tidak terbelenggu pada tindak-tindak pidana tertentu yang bersifat serius saja. Konsep tindakan apa saja yang dapat dilaporkan ini dapat melihat referensi Witness Protection Act 112 of 1998 dan Protected Disclosure Act 26 of 2000. Pada pokoknya, batasan tindak pidana harus dihapus karena tujuannya adalah untuk melindungi seorang Pengungkap yang keamanan dan keselamatannya akan, sedang atau telah terancam sebagai risiko dari laporan yang ia berikan kepada penegak hukum. Lebih lanjut, orientasinya tidak hanya untuk pada hukum pidana khusus saja namun juga tindak pidana secara keseluruhan.

Seorang Pelapor hanya dapat menjadi Saksi Pelapor apabila Pelapor tersebut mengetahui, melihat dan mengalami sendiri secara langsung terhadap tindak 
pidana yang ia laporkan, namun dengan syarat Pelapor tersebut bersedia dan setuju secara sukarela untuk menjadi Saksi Pelapor, lebih lanjut Pelapor dapat menolak untuk menjadi seorang Saksi Pelapor atas dasar terancamnya keselamatan Pelapor.

\section{PENUTUP}

Konsep hukum Pelapor yang ada dalam hukum positif di Indonesia saat ini, secara garis besar mengkonsepkan Pelapor sebagai seorang yang mengetahui dan memberikan laporan atau informasi dalam konteks hukum tindak pidana tertentu yang bersifat serius seperti tindak pidana korupsi, terorisme, tindak pidana narkotika, tindak pidana pencucian uang, perdagangan orang, maupun tindak pidana lainnya yang bersifat terorganisir dan melaporkannya kepada penegak hukum atau pejabat yang berwenang.

Dengan merujuk pada aturan yang ada di Afrika Selatan yaitu Witness Protection Act 112 of 1998 dan Protected Disclosures Act 26 of 2000, konsep hukum Pelapor di Indonesia di masa yang akan datang selain berfokus pada penegakan hukum dapat berfokus pula terhadap penanggulangan. Selain itu, konsep hukum Pelapor yang baru juga dirumuskan dengan menghapus batasan Pelapor dalam hal memberikan laporan agar tidak terbelenggu pada tindak-tindak pidana tertentu yang bersifat serius saja dengan tujuan untuk melindungi seorang Pelapor yang tidak hanya berorientasi pada hukum pidana khusus saja namun juga tindak pidana secara keseluruhan.

\section{BIBLIOGRAFI}

\section{Buku}

Kasiyanto, Agus. Tindak Pidana Korupsi Pada Proses Pengadaan Barang \& Jasa. Jakarta: Kencana, 2018.
Mulyadi, Lilik. Perlindungan Hukum Whistleblower dan Justice Collaborator dalam Upaya Penanggulangan Organized Crime. Bandung: Alumni, 2015.

UNODC. Praktek Terbaik Perlindungan Saksi Dalam Proses Pidana Yang Melibatkan Kejahatan Terorganisir. Jakarta : Lembaga Perlindungan Saksi dan Korban (LPSK), 2010.

\section{Jurnal}

Lewis, David and Tina Uys. "Protecting Whistleblowers at Work a Comparison of the Impact of British and South African Legislation." Managerial Law 49, no. 3 (2007): 87. https://www.emerald.com/insight/content/doi/10.1108/03090550710816492/ full $/ \mathrm{html}$.

Lubisi, S. and H. Bezuidenhout. "Blowing the whistle for personal gain in the Republic of South Africa: An option for consideration in the fight against fraud ?." Southern African Journal of Accountability and Auditing Research 18 (2016): 56. http://hdl. handle.net/2263/58603.

Hikmawati, Puteri. "Upaya Perlindungan Whistleblower dan Justice Collaborator dalam Tindak Pidana Korupsi." Negara Hukum 4, No. 1 (2013): 102. https://jurnal.dpr.go.id/index.php/hukum/article/ view/197.

Muhammad, Rusli. "Pengaturan dan Urgensi Whistle Blower dan Justice Collaborator dalam Sistem Peradilan Pidana." Jurnal Hukum IUS QUIA IUSTUM 22, No. 2 (2015): 214. https://journal.uii.ac.id/index. php/IUSTUM/article/view/5117.

\section{Internet}

Jason, Andre. 'Kasus 'Papa Minta Saham' Dan Kondisi Whistleblowing Di Indonesia." Medium. Last modified 2017. Accessed May 14, 2020. https://medium. 
com/@andrejason14/kasus-papa-mintasaham-dan-kondisi-whistleblowing-di-indonesia-1c2bf3ae20bc.

"Dua Pelapor (Whistleblower) Korupsi Yang Dilindungi LPSK Justru Terancam Masuk Penjara." (ICJR) Institute For Criminal Justice Reform. Last modified 2017. Accessed May 2, 2020. https://icjr.or.id/ dua-pelapor-whistleblower-korupsi-yangdilindungi-lpsk-justru-terancam-masukpenjara/.

"Kerap Lihat Anak Yang Masih Balita Dianiaya, Sang Ibu Tak Berani Laporkan Suami Kedua ke Polisi". WartaKotaLive. Last modified 2020. Accessed September 4, 2020. https://wartakota.tribunnews. com/2020/07/17/kerap-lihat-anak-yangmasih-balita-dianiaya-sang-ibu-tak-berani-laporkan-suami-kedua-ke-polisi. 